\title{
The impact of water scarcity on economic development initiatives"
}

\author{
James Blignaut* and Jan van Heerden \\ Department of Economics, University of Pretoria, Pretoria 0002, South Africa
}

\begin{abstract}
South Africa's unallocated water resources have dwindled to precariously low levels. Furthermore, it is generally recognised by the authorities and specialists alike that it is likely that water demand will outstrip water supply within the next decade. Macro-economically and strategically speaking, the question therefore is how to make best use of the country's available water resources?

We ask this question since South Africa is a country classified as having chronic water shortages, a condition exacerbated by climate change and the presence of invasive alien plant species. In this paper we address the question of sectoral water allocation by applying a macro-economic comparative static Computable General Equilibrium (CGE) Model using an integrated database comprising South Africa's Social Accounting Matrix (SAM) and sectoral water use balances. We refer to AsgiSA, the South African Government's Accelerated and Shared Growth Initiative for South Africa, and conclude that introducing the proposed programmes in a business-as-usual and water-intensive manner will strengthen the current growth in the demand for water. This will bring forward, or accelerate, the need for introducing water rationing among sectors.

The importance of this conclusion cannot be emphasised enough. Water is essential, and recognised in as much in the preamble to the National Water Act of 1998, with regards to livelihoods, health and from a socio-economic development perspective since there are no substitutes for it. While water rationing is imminent, the reality thereof has not yet led to a rethink of macro-economic policies. This delayed effect can create a degree of comfort and ill-founded complacency leading to non-action, whereas there is an urgent need for proactive measures towards water conservation.
\end{abstract}

Keywords: Water demand, Water supply, AsgiSA, economic development, Computable General Equilibrium (CGE) Model, water rationing

\section{Introduction}

Water is indispensable for life. It is also indispensable for economic activities. Water supply in South Africa, however, is limited, unevenly distributed, and negatively impacted by both changes in climate (Blignaut et al., 2009) and the prevalence and spread of invasive alien plant species (Cullis et al., 2007 and Blignaut et al., 2007). The recognition of the country's precarious water supply conditions has led to innovative initiatives to address it, albeit marginally, such as the water neutral scheme developed and operated by WWF-SA (Nel et al., 2009). In this paper, however, we consider the implications for water use, and the imminent need for water rationing, in the light of macro-economic policy directives. We consider the impact on both the macro-economy and on water use of the proposed 6 presidency-led AsgiSA (Accelerated and Shared Growth Initiative for South Africa) water-intensive projects. To do so we provide background concerning South Africa's water demand and supply situation. We then discuss AsgiSA, followed by the model and the results.

\section{Background}

DWAF (2004) estimates that in 2000 South Africa had a total reliable surface water supply of $13226 \times 10^{6} \mathrm{~m}^{3}$. In the

\footnotetext{
\# Revised version. Paper originally presented at the TIPS Forum (Blignaut and Van Heerden, Cape Town) on 30 October 2008 under the title: Is Water Shedding Next?

* To whom all correspondence should be addressed.

욜 +2784 720-4127; fax: +2786 5178647 ; e-mail: james@jabenzi.co.za

Received 26 November 2008; accepted in revised form 29 June 2009.
}

same year, the nation used $13041 \times 10^{6} \mathrm{~m}^{3}$ (including an allocation for the ecological Reserve), leaving a surplus of only $186 \times 10^{6} \mathrm{~m}^{3}$ or $1.4 \%$ of the supply (at $98 \%$ assurance of supply) for that year. Additionally, 12 of the country's 19 water catchments recorded water deficits, which have only been offset by an intricate system of engineered inter-basin water transfer schemes. These worrisome statistics are supported by the Water Resource Accounts for South Africa: 1995 \& 2000 produced by Statistics South Africa (SSA, 2006). In theory, as the remaining annual supply of a vital natural resource approaches zero - crossing clearly identifiable thresholds of scarcity - the marginal value of the resource approaches infinity (Farley and Gaddis, 2007). This implies that the economic value of the last $1.4 \%$ of unutilised water resource becomes very high, far exceeding that of the prevailing bulk water tariff, which is a cost-recovery-based tariff.

Moreover, the meagre water reserve mentioned above actually includes the water imported from neighbouring Lesotho through large-scale engineering projects involving large dams and tunnels. Unutilised domestic sources of water of significant size are extremely limited and largely confined to 2 river catchments in the ecologically sensitive and relatively undeveloped Eastern Cape Province. Water supply constraints are therefore an issue with unparalleled economic development implications. Other supply options are limited and expensive and include desalination, the use of underground aquifers, wastewater reuse, the additional import of water from Lesotho, and lastly the import of water from the Congo River. These options would be costly and, for the most part, highly capital intensive. Their implementation will have a significant effect on water tariffs with the result of making drinking water less accessible to those who are most in need. 


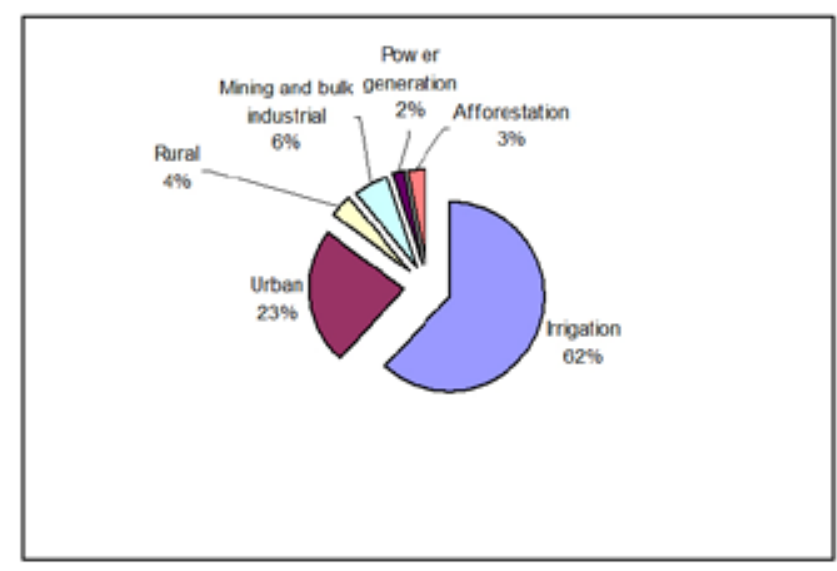

Figure 1

Water requirements by sector in South Africa in 2000 Source: SSA (2006)

\section{Surface water use}

Irrigated agriculture - consuming $62 \%$ - is by far the largest single surface water user, with agriculture and forestry combined consuming $65 \%$ of the total available water resource (see Fig. 1) (SSA, 2006). Commercial farmers use $95 \%$ of agriculture's share, predominantly for irrigation (Schreiner and Van Koppen, 2002). Much of the irrigation is provided by way of centre-pivot systems, supported by intricate canals and water reservoirs (dams) developed more than 50 years ago. These large open water bodies, together with South Africa's climate and geological formations contributes to the fact that about $90 \%$ of the annual precipitation is lost to evapotranspiration and deep seepage (CSIR, 2001). Irrigation's surface area water use has increased steadily from $7630 \times 10^{6} \mathrm{~m}^{3}$ in 1995 to $7921 \times 10^{6} \mathrm{~m}^{3}$ in 2000 , an increase of $291 \times 10^{6} \mathrm{~m}^{3}$, or $4 \%$ (DWAF, 2004). This growth in absolute water use between 1995 and 2000 represents $160 \%$ of the total water surplus remaining at the end of 2000. Furthermore, the total increase in water consumption for all sectors from 1995 to 2000 was $348 \times 10^{6} \mathrm{~m}^{3}$. While it is to be expected that water consumption has to increase as population and the economy grows, the rate at which water use increases, however, far exceeds that.

\section{Groundwater use}

In addition to the increased use of surface water, the use of groundwater is also increasing rapidly (Vegter, 2001; Botha, 2005). Vegter (2001) estimates that by 1999 there were approximately $1.1 \times 10^{6}$ water boreholes in the country, compared to only 225000 recorded on the National Groundwater Database. From drilling data and agricultural records, Vegter (2001) calculates that the groundwater use in 1999 was about $3360 \times 10^{6} \mathrm{~m}^{3} / \mathrm{a}$ and increasing at $3.4 \%$ per year. The estimated use at the end of 2001 was approximately $3850 \times 10^{6} \mathrm{~m}^{3}$, which is $49 \%$ of the surface water usage. These values are, however, contested by DWAF (2006) that states that annual abstraction is approximately $1100 \times 10^{6} \mathrm{~m}^{3} / \mathrm{a}$, which is only $30 \%$ that of Vegter's estimates. To complicate matters further, there is no single definition defining and determining the groundwater resource. DWAF (2006), using a narrow definition, estimates that utilisable groundwater exploitation potential during normal rainfalls years is $10353 \times 10^{6} \mathrm{~m}^{3} / \mathrm{a}$, which declines to $7536 \times 10^{6} \mathrm{~m}^{3} / \mathrm{a}$ during periods of drought. These values are also supported by SSA (2006). Using a broader defini- tion, DWAF (2006), estimates that the average groundwater exploitation potential of aquifers is $19073 \times 10^{6} \mathrm{~m}^{3} / \mathrm{a}$ declining to $16253 \times 10^{6} \mathrm{~m}^{3} / \mathrm{a}$ during a drought. Groundwater usage is therefore estimated to be between $6 \%$ of the resource (using DWAF's usage figures and its higher resource figure), and 51\% (using Vegter's usage figure in conjunction with DWAF's conservative estimate of the size of the resource).

One way to reduce the rate of increase of water use is by increasing the user charges for water. The reduction of the rate of increase will 'release' more water for future consumption and delay the need for water rationing.

\section{Water: The limiting factor}

Clearly, the growth in demand for water compared to the supply constraints is leading to an untenable situation and implies not only that water conservation would have to be applied, but also that profound efforts at redistribution of water would have to take place. This is a fact recognised by DWAF (2004) who stated that, given the demographic trends, South Africa as a whole is likely to have a water deficit of approximately $1.7 \%$ by 2025 . The amount of surplus water available for utilisation of any kind is therefore declining fast, implying that water is becoming a very scarce resource - even the limiting factor to development - as eloquently articulated by Scholes (2001:51) in the following words (see also Daly and Farley, 2004; Aronson et al., 2006; Farley and Daly, 2006):

The availability of water of acceptable quality is predicted to be the single greatest and most urgent development constraint facing South Africa. Virtually all the surface waters are already committed for use, and water is imported from neighbouring countries. Groundwater resources are quite limited; maintaining their quality and using them sustainably is a key issue.

Water use cannot continue to grow at current rates indefinitely given the supply constraints, the likely decline in the water availability due to changes in climatic conditions, the socioeconomic and demographic pressure to increase the use of potable water for domestic use, and to allocate water to higher value-added industries (Blignaut et al., 2009).

For the time being, the effect on agriculture of the changes in climatic conditions over the past 4 decades - notably the $6 \%$ decline in mean annual rainfall (Blignaut et al., 2009) - has been mitigated by the increase in water use from both surface and groundwater resources as indicated above. Future water use patterns will, however, have to adapt to changing climatic conditions and the demand for water by other sectors. This will have obvious implications for food security, future irrigation methods, the type and structure of agriculture production, the way in which land reform is being conducted, and the rural economy in general (Blignaut, 2009). These are all complex interrelated issues that cannot be adequately addressed within the scope of this paper. In the next section we focus our analysis on the implications of the effects that AsgiSA could have on water demand.

\section{AsgiSA}

AsgiSA is an initiative led by the Deputy-Presidency's Office that commenced in 2004. The stated objective of AsgiSA is to accelerate economic growth and seek to distribute the benefits thereof so that all people might share in the growing prosperity of the country (The Presidency, 2009). The AsgiSA task force 
included the Ministers of Finance; Trade and Industry; and Public Enterprises; the Premiers of Gauteng and Eastern Cape Provinces; and the Mayor of Johannesburg who represented the South African Local Government Association. AsgiSA hence became a rallying point towards a common macro-economic policy and the implementation thereof. As far as economic growth targets are concerned, AsgiSA states (The Presidency, not dated: 3 ):

Government's investigations, supported by some independent research, indicate that the growth rate needed for us to achieve our social objectives is around 5\% on average between 2004 and 2014. Realistically assessing the capabilities of the economy and the international environment, we have set a two-phase target. In the first phase, between 2005 and 2009, we seek an annual growth rate that averages $4.5 \%$ or higher. In the second phase, between 2010 and 2014, we seek an average growth rate of at least $6 \%$ of gross domestic product.

To achieve these stated targets, AsgiSA has listed 12 flagship projects in the AsgiSA Summary Document. These projects should contribute significantly towards achieving the abovementioned growth targets and are as follows (The Presidency, n.d.:8):

1 A biofuel initiative that will cover parts of at least Northern Cape, Free State, KwaZulu-Natal, Eastern Cape and Mpumalanga.

2 The Makhathini Cassava and Sugar Project in KwaZuluNatal.

3 A national livestock project that would particularly focus on the Northern Cape and North-West.

4 The Umzimvubu Catchment and Timber Industries Development Initiative in the Eastern Cape.

5 The Dilokong Platinum Corridor to integrate development located around the planned De Hoop Dam in Limpopo.

6 A water reticulation project for Mokopane-VaalwaterMarken in Limpopo.

7 The proposed Square Kilometre Array and linked projects in the Northern Cape.

8 The Cape Flats Infrastructure Project in the Western Cape.

9 A diamond and gemstone jewellery project in the Northern Cape.

10 A Moloto Corridor Rail Project, mostly in Mpumalanga.

11 Gauteng-Durban Corridor including Johannesburg City Deep, Harrismith Hub and Durban Dube Trade Port.

12 The Johannesburg International Airport Logistics Hub and Industrial Development Zone in Gauteng.

While one cannot criticise AsgiSA's objective and ideals stated, it is disconcerting that the first 6 projects listed above are all water-intensive. It seems as though these projects were identified in complete isolation from or oblivious to the fact that South Africa is a water-scarce and arid country, considering the profile of water availability provided earlier. The following section will consider the impact that these projects could have on the availability of water.

\section{Materials and methods}

\section{Model}

The model used in the analysis is called UPGEM (University of Pretoria's Gempack Model), which is a macro-economic Computable General Equilibrium (CGE) Model of South Africa (Van
Heerden et al., 2006a, 2006b and Letsoalo et al., 2007). This model is similar to the ORANI-G model of the Australian economy, which is fully presented and explained by Horridge (2002). It also has a theoretical structure that is typical of most static CGE models and consists of the following blocks of equations:

- Producers' demands for produced inputs and primary factors

- Producers' supplies of commodities

- Demands for inputs for capital formation

- Household demands

- Export demands

- Government demands

- The relationship of basic values to production costs and to purchasers' prices

- Market-clearing conditions for commodities and primary factors

- Numerous other macro-economic variables and price indices (Van Heerden et al., 2008).

Conventional, neoclassical assumptions drive all private agents' behaviour in the model. Producers minimise cost while consumers maximise utility, resulting in the corresponding demand and supply equations of the model. The agents are assumed to be price takers, with producers operating in competitive markets, which prevent the earning of pure profits. In general, the static model with its overall Leontief production structure allows for limited substitution on the production side, and more substitution possibilities in consumption. The implications of using a static model are that solutions are not generated for various time periods, and forecasting is not done by industry. The model is shocked once and allowed to search for a new equilibrium, and those answers are reported. However, this does not mean that long run results could not be found. To clarify further, in this model, nothing could be substituted for water and hence the reference to 'limited substitution'. The model does, however, allow for better technology when water becomes more expensive. The long run could still be simulated and the effects of policies determined using a static model. It has constant elasticity of substitution (CES) sub-structures for the:

- Choice of labour, capital and land

- Choice of the different labour types in the model

- Choice of imported and domestic inputs into the production process.

Household demand is modelled as a linear expenditure system that differentiates between necessities and luxury goods, while households' choices between imported and domestic goods are modelled using the CES structure.

\section{Data}

The CGE model is based on the 1998 Social Accounting Matrix of South Africa. It shows the flows of funds between all players in the economy, such as industries, households, the government and the foreign sector. To model the effects of policy scenarios on water demand, some additional data were required (see Table 1). In principle, for each industry we added the following:

- The quantity of 'taxable water' used. Taxable water is defined as being applicable to metered water use where it is physically possible to ask a price for its consumption. This roughly corresponds to raw water abstracted from rivers while it excludes rain falling on a household's lawn, it does include rain falling on exotic tree plantations (forestry). 


\begin{tabular}{|c|c|c|c|c|c|}
\hline \multicolumn{6}{|c|}{$\begin{array}{c}\text { TABLE } 1 \\
\text { Taxable water, water tariffs }(2002) \text { and the semi-elasticity for water } \\
\text { demand }\end{array}$} \\
\hline & (1) & $\begin{array}{c}(2) \\
\text { Taxable } \\
\text { water } \\
(\mathrm{million} \\
\left.\mathrm{m}^{3}\right) \\
\end{array}$ & $\begin{array}{l}\text { (3) Water } \\
\text { tariff } \\
\left(\mathrm{R} / \mathrm{m}^{3}\right)\end{array}$ & $\begin{array}{l}\text { (4) Elas- } \\
\text { ticity }\end{array}$ & $\begin{array}{l}\text { (5) Semi- } \\
\text { elasticity }\end{array}$ \\
\hline Irrigated field crops & $\mathrm{A}$ & 7152 & 0.10 & -0.25 & -44.20 \\
\hline Dry land & A & 0 & 0.10 & -0.15 & 0.00 \\
\hline Irrigated farming & $\mathrm{A}$ & 3400 & 0.10 & -0.25 & -44.20 \\
\hline Dry horticulture & $\mathrm{A}$ & 0 & 0.10 & -0.15 & 0.00 \\
\hline Livestock & $\mathrm{A}$ & 191 & 0.10 & -0.15 & -37.73 \\
\hline Forestry & & 1673 & 1.80 & n.a. & 0.00 \\
\hline Other Agric & $\mathrm{A}$ & 25 & 0.10 & -0.15 & -26.54 \\
\hline Coal & $\mathrm{B}$ & 40.3 & 2.12 & -0.32 & -47.654 \\
\hline Gold & B & 284.8 & 2.12 & -0.32 & -47.654 \\
\hline Crude, petroleum \& gas & $\mathrm{B}$ & 0.74 & 2.12 & -0.48 & -88.02 \\
\hline Other mining & B & 368.3 & 2.12 & -0.32 & -47.654 \\
\hline Food & & 376.4 & 4.00 & -0.39 & -49.050 \\
\hline Textiles & & 104.4 & 4.00 & -0.33 & -41.325 \\
\hline Footwear & & 0 & 4.00 & -0.33 & -41.325 \\
\hline Chemicals \& rubber & $\mathrm{B}$ & 59.4 & 2.12 & -0.15 & -22.576 \\
\hline Petroleum refineries & $\mathrm{B}$ & 92 & 2.12 & -0.48 & -70.656 \\
\hline Other non-metal minerals & $\mathrm{B}$ & 44 & 2.79 & -0.32 & -43.986 \\
\hline Iron \& steel & $\mathrm{B}$ & 56.21 & 2.79 & -0.27 & -37.017 \\
\hline Non-ferrous metal & $\mathrm{B}$ & 14.04 & 2.79 & -0.27 & -37.017 \\
\hline Other metal products & $\mathrm{B}$ & 60 & 2.79 & -0.27 & -37.017 \\
\hline Other machinery & & 37.27 & 4.00 & -0.25 & -47.500 \\
\hline Electricity machinery & & 6.23 & 4.00 & -0.38 & -47.713 \\
\hline Radio & & 0 & 4.00 & -0.38 & -47.713 \\
\hline Transport equip & & 20.42 & 4.00 & -0.38 & -47.713 \\
\hline Wood, paper \& pulp & $\mathrm{B}$ & 157.5 & 2.12 & -0.59 & -86.609 \\
\hline Other manufacturing & & 13 & 4.00 & -0.38 & -47.713 \\
\hline Electricity & $\mathrm{B}$ & 208 & 2.12 & -0.80 & -328.17 \\
\hline Water & $\mathrm{B}$ & 5906.0 & 2.12 & -0.60 & -88.302 \\
\hline Construction & & 167.12 & 4.00 & -0.38 & -47.713 \\
\hline Trade & & 491.4 & 4.00 & -0.19 & -23.750 \\
\hline Hotels & & 319.8 & 6.11 & -0.19 & -22.110 \\
\hline Transport services & & 497.11 & 6.11 & -0.19 & -22.110 \\
\hline Community services & & 175.8 & 6.11 & -0.19 & -22.110 \\
\hline Financial Institutions & & 281.3 & 6.11 & -0.19 & -22.110 \\
\hline Real estate & & 662 & 6.11 & -0.19 & -22.110 \\
\hline Business activities & & 26.2 & 6.11 & -0.19 & -22.110 \\
\hline General government & & 524.76 & 6.11 & -0.19 & -22.110 \\
\hline Health services & & 331.3 & 6.11 & -0.19 & -22.110 \\
\hline Other service activities & & 198.74 & 6.11 & -0.19 & -22.110 \\
\hline
\end{tabular}

Note: Sectors marked A are agricultural - large users of water who pay little in the form of volumetric charges. Those marked B are bulk users of non-potable water.

Sources: Semi-elasticities are derived from DWAF's water tariff table and survey conducted among large water utilities, DBSA, 2000; Renzetti, 1992; Veck and Bill, 2000; Le Maitre et al., 2000; and Letsoalo et al., 2007.
- A semi-elasticity showing how water intensity (water use per unit of output) might change in response to a change in volumetric water charges. A semi-elasticity is an elasticity which is calculated as the ratio of the per cent changes in two variables. If the variable in the denominator starts from zero it is impossible to calculate a per cent change, and hence one divides through the absolute change instead to get the 'semielasticity'.

Column 1 of Table 1 indicates 3 main sectors. Those marked A are in the agricultural sector - large users of water who pay various volumetric charges. Those marked B are bulk users of non-potable water. Unmarked sectors are mostly consumers of potable water delivered by water utilities. We distributed the raw water used by the (municipal) water industry among remaining industrial and household users of treated water. For forestry, we have incorporated an estimate of the streamflow loss caused by exotic species (as compared to native species). Column 2 of Table 1 shows quantities of water used. Column 3 shows a range of water tariffs (for 2002) following a survey done among large water utilities, and Column 4 shows elasticities derived from various sources as listed below the table, notably Letsoalo et al. (2007). We estimated semi-elasticities (Column 5) that should be interpreted as the percentage change in water use per unit change in the marginal cost of water, adapted to allow for sector-specific variations.

\section{The scenarios}

The modelling task at hand was to determine the economy-wide impacts on GDP, employment, and water consumption for each of the following three scenarios:

1 In Scenario 1, we inject R1 bn. into each of 9 sectors linked to the 12

AsgiSA projects listed above. These sectors are:

- Dry field agriculture (Project 1)

- Irrigation horticulture (Project 2)

- Livestock (Project 3)

- Timber (Project 4)

- Other mining (Project 5)

- The water sector (Project 6)

- Communication (Project 7)

- Construction (Projects 8 and 10-12)

- Other non-metal minerals (Project 9) 
2 In Scenario 2, we increased all water tariffs by $1 \mathrm{c} / \mathrm{m}^{3}$, including water that has not been taxed or priced before. This would include all registered water used from rivers or from boreholes. We expect that such an increase in tariffs would result in a decrease in water demand, to show one possible way of saving water. It should be noted that the purpose of this paper is not to find the best way to save water, but rather to illustrate that any government initiative to stimulate growth needs to consider the effects on available water.

3 In Scenario 3, we recycle the tax revenue collected from the increased or new water tariffs (Scenario 2) back to the 'AsgiSA' sectors, and report the net effects on GDP, unskilled employment, and water demand. Recycling this revenue (which is about $\mathrm{R} 175 \mathrm{~m}$. and hence much smaller than R1 bn.) would stimulate the various industries and have positive effects on GDP and unskilled employment.

\section{Results}

The results of modelling the scenarios as described above are depicted in Table 2. Should government invest R1 bn. in each of the 9 sectors (Scenario 1), the total increase in GDP would be $0.53 \%$, i.e. the policy shock to the model constitutes an $0.53 \%$ increase on the value of GDP, with the largest contribution coming from the livestock and timber plantation sectors. Employment of unskilled labour would increase by 1.3\%, mainly from the aforementioned 2 sectors as well, but water demand would increase by $2.2 \%$, mainly from the irrigation, timber and water provisioning sectors. The increase in demand for water would therefore outstrip its contribution to GDP by several orders of magnitude (given that no efficiency gains can be derived) and, what is more, this increase is $50 \%$ more than the current available surplus supply of water of $1.4 \%$. This does not imply that these projects could not be implemented; it only states that once they are implemented there would be less water for other projects. Another pertinent point is that the water intensity of the 9 sectors is far from the same. Approximately $91 \%$ of the total $2.2 \%$ increase in water demand originates from 3 sectors only, namely, irrigation agriculture $(0.78 \%)$, timber $(0.627 \%)$ and the water sector $(0.584 \%)$. While their combined impact on water consumption is $2 \%$, their contribution to GDP is only $0.22 \%$ and to employment of unskilled labour only $0.6 \%$. The impact on water consumption is therefore disproportionately more than their impact on the general economy - i.e. the AsgiSA objectives. This illustrates the fact that when considering projects, the sectors selected matter.

If we increase water tariffs uniformly by $1 \mathrm{c} / \mathrm{m}^{3}$ without recycling the revenue (Scenario 2), the result is a decline in GDP of $0.011 \%$, while the decrease in water demand is $2.51 \%$. The proportional decline in GDP is much less than the reduction in water consumption, so that we would be able to see a net saving in water demand with such a policy measure.

The $3^{\text {rd }}$ column of Table 2 (Scenario 3) shows that almost all the water saved in Scenario 2 remains saved even if the water tax revenue is recycled. Four industries show 'GDP dividends', which means that the net effect of the combined water tax and revenue recycling scheme is positive on GDP. These industries are livestock, timber, water and communication. Four industries show 'Unskilled labour dividends' in that the combined policies would have net employment effects for the economy as a whole, namely irrigation horticulture, livestock, timber and water. The latter 3 industries therefore show 'triple dividends' since they show GDP dividends, employment dividends and

\begin{tabular}{|c|c|c|c|}
\hline \multicolumn{4}{|c|}{$\begin{array}{l}\text { TABLE } 2 \\
\text { Results from modelling the implementation of } \\
\text { the } 9 \text { water-intensive AsgiSA projects on GDP, } \\
\text { employment, and water demand }\end{array}$} \\
\hline & \multicolumn{3}{|c|}{$\%$ change in } \\
\hline & GDP & $\begin{array}{c}\text { Unskilled } \\
\text { labour }\end{array}$ & $\begin{array}{c}\text { Water } \\
\text { use }\end{array}$ \\
\hline \multicolumn{4}{|c|}{ Scenario 1: Injection of R1bn. in: } \\
\hline - Dry land (field) agriculture & 0.037 & 0.112 & 0.025 \\
\hline - Irrigation farming & 0.054 & 0.183 & 0.780 \\
\hline - Livestock & 0.091 & 0.223 & 0.099 \\
\hline - Timber & 0.093 & 0.250 & 0.627 \\
\hline - Other mining & 0.045 & 0.098 & 0.021 \\
\hline - Water sector & 0.070 & 0.161 & 0.584 \\
\hline - Communication & 0.070 & 0.112 & 0.037 \\
\hline - Construction & 0.022 & 0.041 & 0.010 \\
\hline - Other non-metal minerals & 0.050 & 0.116 & 0.014 \\
\hline \multicolumn{4}{|c|}{ Scenario 2: Water tariff increase $1 \mathrm{c} / \mathrm{m}^{3}$} \\
\hline & -0.011 & -0.028 & -2.51 \\
\hline \multicolumn{4}{|c|}{ Scenario 3: Water revenue recycled to: (net results) } \\
\hline - Dry land (field) agriculture & -0.0040 & -0.0081 & -2.51 \\
\hline - Irrigation horticulture & -0.0011 & +0.0043 & -2.38 \\
\hline - Livestock & +0.0054 & +0.0112 & -2.49 \\
\hline - Timber & +0.0057 & +0.0160 & -2.40 \\
\hline - Other mining & -0.0026 & -0.0106 & -2.51 \\
\hline - Water sector & +0.0018 & +0.0004 & -2.41 \\
\hline - Communication & +0.0018 & -0.0082 & -2.51 \\
\hline - Construction & -0.0067 & -0.0205 & -2.51 \\
\hline - Other non-metal minerals & -0.0017 & -0.0075 & -2.51 \\
\hline
\end{tabular}

water saving dividends. Remember that the net effect on the government budget is neutral, since all the revenue that is collected through the water tax is recycled back into the economy.

\section{Conclusion}

AsgiSA implies targeting some economic industries or sectors to stimulate growth. In this paper we used a macro-economic model and argue that the stimulation of any industry would increase the demand for water as input into the production process. To illustrate this we have shown that a hypothetical injection into the economy of R1 bn. stimulation to each of 9 targeted industries, would lead to a deficit in the available amount of water. It would therefore be physically impossible to stimulate the 9 industries as planned, unless the necessary water supplies were re-allocated from other sectors. The water tax would decrease the total water demand sufficiently enough to provide for the AsgiSA initiatives, and have some savings left over. Moreover, if we recycle the water tax revenues towards the 9 AsgiSA industries, the negative impact of the water tax is diminished in terms of GDP and employment effects, while a large net saving of water remains.

This analysis shows that macro-economic planning and the design of economic development strategies cannot be done in isolation from considering natural resource constraints. Natural capital is increasingly the limiting factor to development and any investment in economic development should take serious cognisance of these limitations. Here we have not even considered the impacts of climate change (Blignaut et al., 2009) and the prevalence and spread of invasive alien plants (Blignaut et 
al., 2007). Climate change and invasive alien plants are likely to have a detrimental impact on the availability of existing water resources and are likely to reduce the water supply. It is estimated that invasive alien plants by themselves could consume as much as $16 \%$ of water in the near future if left unchecked (Cullis et al., 2007).

This does not imply that AsgiSA should not continue seeking sectors and projects to invest in, but that it should consider resource constraints in an integrative manner. Opportunities should be explored that, through investing in natural capital, would stimulate economic development, create jobs and augment the dwindling supply of natural resources. So, is water rationing next? The answer would be positive if macro-economic decision-making is not conducted in such a way as to acknowledge and plan with implicit resource constraints and bio-physical and hydrological patterns and features.

\section{Acknowledgement}

The authors wish to acknowledge research funding received from ERSA (Economic Research Southern Africa). We also wish to thank 2 anonymous reviewers whose comments have benefited the paper greatly, but the usual disclaimer applies. This paper is based on a presentation at the TIPS Forum in Cape Town on 30 October 2008 under the title: Is Water Shedding Next?

\section{References}

ARONSON J, BLIGNAUT JN, MILTON SJ and CLEWELL AF (2006) Natural capital: The limiting factor. Ecol. Eng. 28 1-5.

BLIGNAUT JN (2009) Fixing both the symptoms and causes of degradation: The need for an integrated approach to economic development and restoration. J. Arid Environ. 73 696-698.

BLIGNAUT JN, UECKERMAN L and ARONSON J (2009) Agriculture production's sensitivity to changes in climate in South Africa. S. Afr. J. Sci. 105 61-68.

BLIGNAUT JN, MARAIS C and TURPIE J (2007) Determining a charge for the clearing of invasive alien plant species to augment water supply in South Africa. Water SA 33 (1) 27-34.

BOTHA FS (2005) A proposed Method to Implement a Groundwater Resource Information Project (GRIP) in Rural Communities, South Africa (Unpublished Ph.D.). Department of Geohydrology, Faculty of Natural Science and Agriculture, University of the Free State, Bloemfontein.

CSIR (2001) Water Resource Accounts for South Africa. Report to Statistics South Africa and The Department of Environment Affairs and Tourism. CSIR Report No. ENV-P-C 2001-050. CSIR, Pretoria, South Africa.

CULLIS J, GÖRGENS A and MARAIS C (2007) A strategic study of the impact of invasive alien vegetation in the mountain catchment areas and riparian zones of South Africa on total surface water yield. Water SA 33 (1) 35-42.

DALY HE and FARLEY J (2004) Ecological Economics. Island Press, Washington DC.

DBSA (DEVELOPMENT BANK OF SOUTHERN AFRICA) (2000) Environmental Impacts of the Forestry Sector in South Africa with Specific Reference to Water Resources. CSIR Report No. ENV-P-C 99016. CSIR, Pretoria, South Africa.
DWAF (DEPARTMENT OF WATER AFFAIRS AND FORESTRY, SOUTH AFRICA (2004) National Water Resource Strategy. Department of Water Affairs and Forestry, Pretoria.

DWAF (DEPARTMENT OF WATER AFFAIRS AND FORESTRY, SOUTH AFRICA (2006) Groundwater Resource Assessment II - Task 2c Groundwater Planning Potential. Department of Water Affairs and Forestry, Pretoria.

FARLEY J and DALY HE (2006) Natural capital: The limiting factor: A reply to Aronson, Blignaut, Milton and Clewell. Eco. Eng. 2 6-10.

FARLEY J and GADDIS E (2007) Restoring Natural Capital: An Ecological Economics Assessment. In: Aronson J, Milton S and Blignaut JN (eds.) Restoring Natural Capital: Science, Business and Practice. Island Press, Washington, DC.

HORRIDGE M (2002) ORANI-G: A Generic Single-Country Computable General Equilibrium Model. Edition prepared for the Practical GE Modelling Course, June 17-21.

LETSOALO A, BLIGNAUT J, DE WET T, DE WIT M, HESS S, TOL RSJ, and VAN HEERDEN J (2007) Triple dividends of water consumption charges in South Africa. Water Resour. Res. 43 W05412, DOI:10.1029/2005WR004076.

LE MAITRE DC, VERSVELD DB and CHAPMAN RA (2000) The impact of invading alien plants on surface water resources in South Africa: a preliminary assessment. Water SA 26 (3) 397-408.

NEL DC, MARAIS C AND BLIGNAUT JN (2009) Investing in water: Evidence from a water neutral program in South Africa. Cons. Letters 2 11-18.

RENZETTI S (1992) Estimating the structure of industrial water demands: the case of Canadian manufacturing. Land Econ. 68 (4).

SCHOLES R (2001) Global Terrestrial Observing System: Regional Implementation Plan for Southern Africa. GTOS-21.CSIR, Pretoria, South Africa, Pretoria.

SCHREINER B and VAN KOPPEN B (2002) Catchment management agencies for poverty eradication in South Africa. Phys. Chem. Earth 27 969-976.

SSA (STATISTICS SOUTH AFRICA) (2006) Water Resource Accounts for South Africa: 1995 \& 2000. Statistics South Africa, Pretoria, South Africa.

THE PRESIDENCY (n.d.) AsgiSA Summary Document. URL: http:// www.info.gov.za/asgisa/asgisa.htm (Accessed February 2008).

THE PRESIDENCY (2009) AsgiSA Annual Report 2008. URL: http:// www.info.gov.za/view/DownloadFileAction?id=98944 (Accessed April 2009)

VAN HEERDEN JH, BLIGNAUT JN and HORRIDGE M (2008) Integrated water and economic modelling of the impacts of water market instruments on the South African economy. Ecol. Econ. 66 (1) $105-116$.

VAN HEERDEN JH, GERLAGH R, BLIGNAUT JN, HORRIDGE M, HESS S, MABUGU R and MABUGU MR (2006a) Searching for triple dividends in South Africa: fighting $\mathrm{CO}_{2}$ pollution and poverty while promoting growth. Energ. $J .26$ (2) 113-141.

VAN HEERDEN JH, BLIGNAUT JN, MABUGU M, GERLAGH R, HESS S, TOL RSJ, HORRIDGE M, MABUGU R, DE WIT MP and LETSOALO A (2006b) Redistributing environmental tax revenue to reduce poverty in South Africa: the cases of energy and water. S. Afr. J. Econ. Manage. Sci. 9 (4) 537-552.

VECK GA and BILL MR (2000) Estimation of the Residential Price Elasticity of Demand for Water by Means of a Contingent Valuation Approach. WRC Report No. 790/1/00. Water Research Commission, Pretoria, South Africa.

VEGTER JR (2001) Groundwater Development in South Africa and an Introduction to the Hydrogeology of the Groundwater Regions. WRC Report No. TT 134/00. Water Research Commission, Pretoria, South Africa. 